\section{Implementation of GYN Robotic surgery in our practice}

\author{
Antony Brigoni, Oksana Mudra \\ American Hospital Dubai, Dubai, UAE
}

The Middle East has launched its first comprehensive robotic surgery program, known as one of the most sophisticated laparoscopic surgical technologies available. The device - created by Intuitive - is part of a new program aimed at enhancing the group's "current comprehensive general surgery and laparoscopic surgery services".

American Hospital was selected as the hub for this robotic program as it is already considered a market leader in advanced laparoscopic surgery.

According to the manufacturer, the da Vinci Xi HD 4 works by combining conventional laparoscopic techniques with high precision robotic technology that uses four robotic arms controlled by the surgeon from a console. Using the console, the surgeon is also able to access a 3D high-definition view of the surgical area.

Robotic surgery is a state-of-the-art surgical procedure where the conventional laparoscopic technique is combined with high-precision robotic technology. Articulated instruments allow the same movement capacity as the human wrist and the tremor filter eliminates any small uncontrollable movement in the surgeon's hands.

\section{OPEN OACCESS}

DOI: $10.25040 / n t s h 2020.02 .12$

For correspondence:

5566 Dubai, Oud Metha str, UAE

E-пошта: abrignoni@me.com oksana12mudra@gmail.com

Received: Sep, 28, 2020

Accepted: Oct, 28, 2020

Published online: Nov , 28, 2020

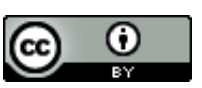

Antony Brignoni, Oksana Mudra, 2020

\section{ORCID IDs}

Antony Brignoni,

https://orcid.org/0000-0002-8203-2668

Oksana Mudra,

https://orcid.org/0000-0003-1868-0190

Conflict of interests: The authors declare no conflict of interests

Disclosure: The authors declare that this study had received no financial support. Submission is original, free of any copied texts, graphics or ideas.

Author Contributions: All authors were equally involved in the preparation of this review. All authors have read and approved the final version of the manuscript.

Funding: This review did not require funding

Ethics approval: Not required for this review.

We would like to share our experience in the implementation of Robotic-Assisted surgery in the gynecological practice of our hospital.

Commencement of our program coincided with a very difficult period for the entire world. Regardless of the COVID pandemic, we successfully launched on our robo- surgical journey, and within 6 months, we performed 150 Robotic-assisted surgeries, with 50 of them being gynecological.

In the last three decades, the gynecologic surgery has been transformed in the western world, from mostly open abdominal surgeries with increased length of stay and morbidity to modern minimally invasive surgeries with a short stay duration, decreased morbidity, faster return to normal activities and work. Long past the days of doing laparoscopic surgery with direct viewing through a scope and poor-quality imaging monitors which are now replaced with our current High definition 2D and 3D imaging. In the last decade, the introduction of Robotics to our surgical armamentarium has steadily increased the likelihood that patients will have a minimally invasive procedure instead of an open laparotomy.

Keywords: Robotic surgery, gynecology, women health, laparoscopy.

Cite this article as: Brignoni A, Mudra O. implementation of GYN robotic surgery in our practice.

Proc Shevchenko Sci Soc Med Sci. 2020, 62(2):139-142. 


\section{OPEN OACCESS}

DOI: $10.25040 /$ ntsh2020.02.12

Для листування:

5566 вул. Уд Мета, Дубай, ОАЕ

E-пошта: abrignoni@me.com oksana12mudra@gmail.com

Стаття надійшла: 28.09.2020

Прийнята до друку: 28.10.2020

Опублікована онлайн: 28.11.2020

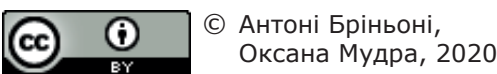

\section{ORCID IDs}

Antony Brignoni,

https://orcid.org/0000-0002-8203-2668

Oksana Mudra,

https://orcid.org/0000-0003-1868-0190

Конфлікт інтересів: Автори декларують, що немає конфлікту інтересів.

Особистий внесок авторів: Всі автори в рівній мірі брали участь у підготовці цього огляду. Всі автори прочитали та затвердили остаточний варіант рукопису.

Фінансування: Підготовка цього огляду не потребувала фінансування.

Дозвіл біоетики: Для даного огляду не потрібний.

\section{Впровадження робототехніки в гінекології:} наш досвід

\author{
Антоні Бріньоні, Оксана Мудра
}

Відділ Акушерства і гінекології, Американський шпиталь Дубаю, OAE

Гінекологічна хірургія трансформувалася за останні три десятиліття в західному світі: від переважно відкритих операцій на черевній порожнині зі збільшенням тривалості перебування в стаціонарі та захворюваності до відомих малоінвазивних операцій з коротким періодом перебування, зниженням захворюваності, швидшим поверненням до звичної діяльності та роботи. Давно минули часи проведення лапароскопічної хірургії з прямим переглядом через приціл-скоп, пізніше неякісні зображення замінили сучасні 2D та 3D зображення високої чіткості. В останнє десятиліття впровадження робототехніки в наш хірургічний арсенал постійно збільшує ймовірність того, що пацієнти будуть мати малоінвазивну процедуру замість відкритої лапаротомії.

Ключові слова: роботизована хірургія, гінекологія, здоров'я жінок, лапароскопія.
Our experience in the implementation of the Robotic program in our institution started not so long ago, in February 2020. Despite complicated times for everyone, the lockdown and the battle with COVID-19 pandemic, our commencement has been crowned with success and positive outcomes in the fields of Gynecology, General Surgery and Urology.

Robotic surgery, or robotic-assisted surgery, allows performing a variety of complex procedures with more precision, flexibility and control than it is possible with conventional Laparoscopy or open abdominal surgery.

The advantages of robotic surgeries include smaller incisions, endo-Wrist articulating instruments, anti-tremor technology leading to enhanced precision during surgery, which lowers the risk of complications, morbidity, ensures less postoperative pain and shorter hospital stay.

The system provides better access, especially in highly complicated procedures when extensive dissection and adhesiolysis are required to reestablish proper pelvic Anatomy.
The three-dimensional (3D) imaging, unlike a two-dimensional (2D) one, provides significantly improved visualization of the surgical area.

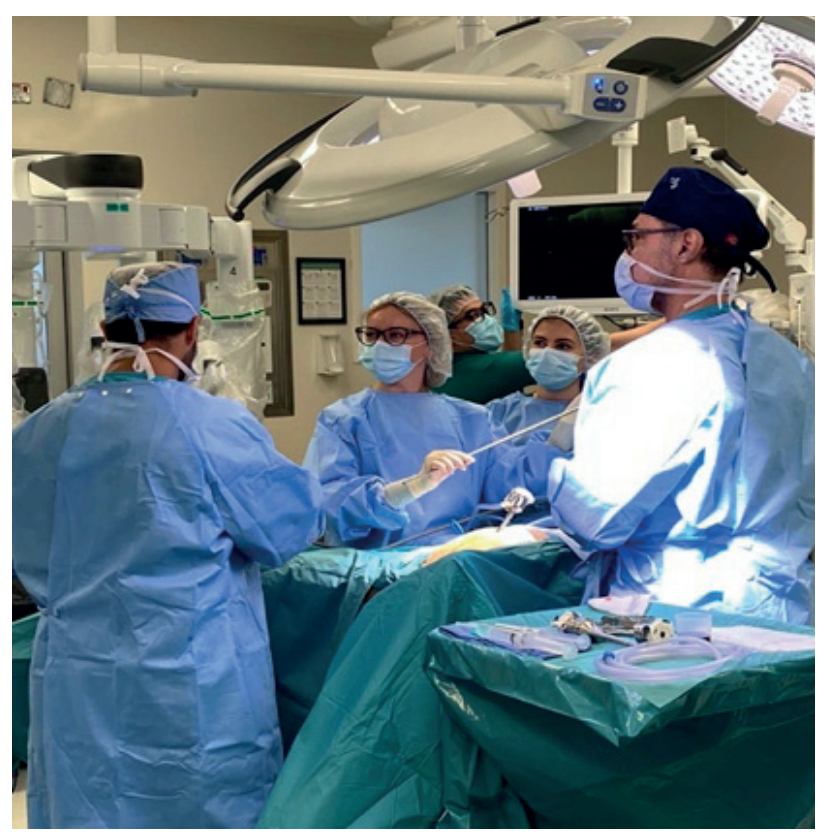

Fig 1. Initial steps of robotic surgery, insertion of ports. 


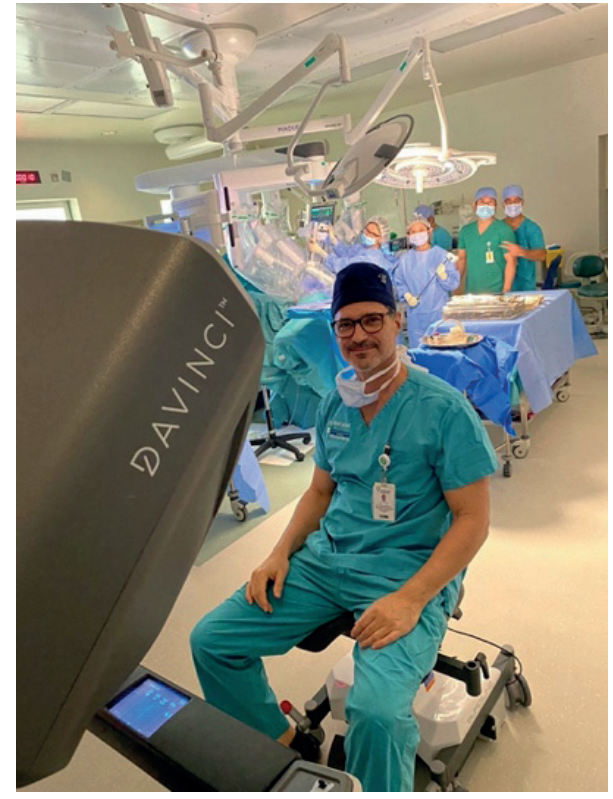

Fig 2. The surgeon controls the surgery while seated at the console, the assisting surgeon and the rest of the team are near the patient.

The surgeon can sit comfortably at a computer console operating Robotic instruments with precise fingertip control (Fig.2). The Tremor reduction technology allows keeping the tools stable while decreasing the surgeon's fatigue.

The main difference with robotic tools compared with conventional laparoscopic tools is that they are articulated - the same range of movements that can be performed by the wrists inside the body is available using these tiny $(1-2 \mathrm{~cm})$ tools and a high-definition 3D view with up to ten times enlargement. Using these features, the surgery can be performed with minimal trauma to the tissue during the procedure, which will result in many the postoperative benefits for the patients.

The most widely used clinical robotic surgical system includes a surgeon's console, a patientside cart with three or four robotic arms. One arm is used for the 3D camera and the other robotic arms are intended for surgical tools.

The surgeon controls robotic arms while seated at a computer console near the operating table. The console gives the surgeon a highdefinition, magnified, 3D view of the surgical field. The surgeon leads other team members who assist during the operation.
The use of robotic assistance in laparoscopy is rapidly becoming popular because of positive postoperative patients' feedback. Over the last 6 months, 50 robotic-assisted gynecological procedures were performed. Most of our gynecological cases are complicated, but we can perform them with robotic-assisted surgeries. We perform all types of noncancerous surgeries, such as myomectomy, hysterectomy, endometriosis resection, tubal anastomosis, and pelvic organ prolapse were performed in our institution. $87 \%$ of all operated patients went home the next day with minimum pain; in $92 \%$ of cases, blood loss was less than 50 $\mathrm{ml}$ (most of the time described as scant or minimum), $0.1 \%$ suffered from the surgical site infection, $91 \%$ of patients required less opioid analgesics in the postoperative period.

Among the disadvantages that we experienced with robotic surgeries was increased surgery time, mainly due to the learning curve, compared to laparoscopy (Fig. 3).

The initial cost of robotic equipment is more expensive too.

Conclusion - The purpose of this article is to highlight the acceptance of robotic surgeries in our Gynecology population, for various

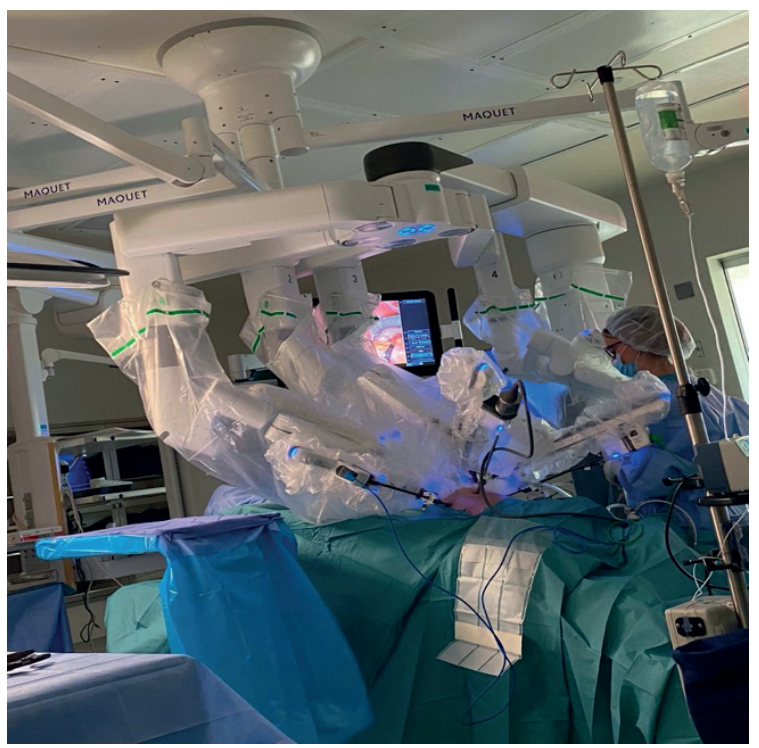

Fig 3. Robotic surgery in process, the assisting surgeon helps through the assistant port.

procedures, like myomectomy, hysterectomy, endometriosis, tubal anastomosis, and 
Праці НТШ Медичні науки 2020, Том 62, № 2 ISSN 2708-8634 (print)

Від редактора

pelvic organ prolapse. Robotic surgery will undoubtedly continue gaining popularity as more gynecologic surgeons are trained in Robotic surgery and more patients seek minimally invasive surgical options.

When it comes to the financial impact of the conventional open surgery, for companies, families, the patient - no one can afford a person being out
Proc Shevchenko Sci Soc Med Sci www.mspsss.org.ua ISSN 2708-8642 (online) 2020, Vol. 62, 2 Editorial

of work for two or three months. There's also the cost of pain medication, antibiotics, an ICU stay, blood transfusions to think about, as well as a risk of infection or hernia resulting from the larger incision.

\section{Footnotes:}

Figures 1-3: written permission of copyright holders for reproduction was obtained $(1.10 .2020)$

\section{References}

1. Diana M, Marescaux J. Robotic surgery. Br J Surg. 2015,102(2):el5-28.10.1002/bjs.9711

2. Sfakianos GP, Frederick PJ, Kendrick JE, Straughn JM, Kilgore LC, Huh WK. Robotic surgery in gynecologic oncology fellowship programs in the USA: a survey of fellows and fellowship directors. Int J Med Robot. 2010, 6(4):405-12.10.1002/rcs.349

3. https://www.intuitive.com/en-us/about-us/company

4. Carbonnel M, Thu N'Guyen $\mathrm{H}$, Abbou H, de la Joliniere JB, Ayoubi JM. Robotic laparoscopy in benign gynecologic surgery: a retrospective study comparing vaginal, laparoscopic and robotic hysterectomy procedures. Reprod Syst Sex Disord. 2013, 2(2):1-4.

5. AAGL Advancing Minimally Invasive Gynecology Worldwide. AAGL position statement: robotic-assisted laparoscopic surgery in benign gynecology. J Minim Invasive Gynecol (2013) 20(I):2-9.10.1016/j. jmig.2012.12.007 [PubMed] [CrossRef] [Google Scholar]

6. Paraiso MF. Robotic-assisted laparoscopic surgery for hysterectomy and pelvic organ prolapse repair. Fertil Steril. 2014, 102(4):933-8.10.1016/j.fertnstert.2014.08.010

7. Wright JD, Ananth CV, Lewin SN, Burke WM, Lu YS, Neugut AI, et al. Robotically assisted vs laparoscopic hysterectomy among women with benign gynecologic disease. JAMA. 2013, 309(7):689-98.10.1001/ jama.2013.186

8. Nawfal AK, Orady M, Eisenstein D, Wegienka G. Effect of body mass index on robotic-assisted total laparoscopic hysterectomy. J Minim Invasive Gynecol, 2011;18(3):328-32.10.1016/j.jmig.2011.01.009

9. Orady M, Nawfal AK, Wegienka G. Does size matter? The effect of uterine weight on robot-assisted laparoscopic hysterectomy outcomes. J Robot Surg. 2011, 5:267-72.10.1007/s11701-011-0271-X

10. Payne TN, Dauterive FR, Pitter MC, Giep HN, Giep BN, Grogg TW, et al. Robotically assisted hysterectomy in patients with large uteri: outcomes in fi ve community practices. Obstet Gynecol (2010) 115(3):53542.10.1097/AOG.0b013e3181cf45ad

11. Orady M, Hrynewych A, Nawfal AK, Wegienka G. Comparison of robotic-assisted hysterectomy to other minimally invasive approaches. JSLS (2012) 16(4):542-8.10.4293/108680812X13462882736899 